France

\section{Cap la Hague restarted}

THE accident at the reprocessing plant at Cap la Hague which resulted in the total loss of electric power a fortnight ago (Nature, 24 April, page 653) may have been the result of circuit overloading according to the CFDT, the main union representing nuclear workers at the plant. A spokesman for the union told Nature that some of the power supply equipment was 15 years old and had been initially designed for the reprocessing of low activity spent fuel only. However, high activity fuel was now reprocessed there although the plant had not been fully upgraded to cope with the increased current this demanded.
According to reports in the Guardian, Cogema decided to restart operations last week after receiving clearance from the Ministry of Industry. A spokesman for Cogema had said that radiation levels were acceptable. Workers at the plant, however, were worried that several parts of the plant were still highly contaminated. According to the CFDT spokesman, an expert who had visited the plant had recommended that it should not be restarted. The director however, decided to go ahead.

The union met at the end of last week to discuss how to react to Cogema's decision to restart operations even though full repairs have not been carried out. In the absence of any detailed technical report, no agreement on what action to take was reached except that the union's concern over the decision should be expressed.

Cogema's desire to restart only eight days after the accident is seen as a move to reprocess spent fuel already stored at the plant to make room in the storage ponds for a consignment of Japanese spent fuel awaiting shipment in the UK. Workers believe that as soon as this backlog is cleared, the plant will be closed in two to three weeks time for full repairs.

\section{Mozambique}

\section{The politics of African archaeology}

THE opening of a new museum at Manyikeni in Mozambique marks a change in the presentation of archaeology in Southern Africa.

At issue are the "Zimbabwes" - a chain of 150 ancient settlements characterised by central stone-walled enclosures spread across Mozambique and what is now called Zimbabwe. White settlers in Rhodesia argued that the stone walls were Egyptian temples built by the Queen of Sheba, while the Portuguese in Mozambique opted for their construction by mythical Lusitanians.

As early as 1905, the British Egyptologist, Randal Mclver, established that not only were the ruins not Egyptian, but that they were built in the past 1000 years, and thus necessarily by local, black, people. Later all other archaeologists agreed. But that answer was totally unacceptable to the white settlers, who stuck by the Queen of Sheba.

The advent of scientific archaeology made this position increasingly untenable. The first carbon tests in the 1950s suggested that Great Zimbabwe, after which the country Zimbabwe has taken its name, was built around 1000 years ago. (Great Zimbabwe was the most striking of these settlements and with a population of 10,000 , must have been the largest city in southern Africa at its peak in 1400.)

A guidebook to Great Zimbabwe published in the early 1960 s contained the carbon dates and dismissed the Queen of Sheba explanations. In the late 1960 s and early 1970 s much better carbon dates were

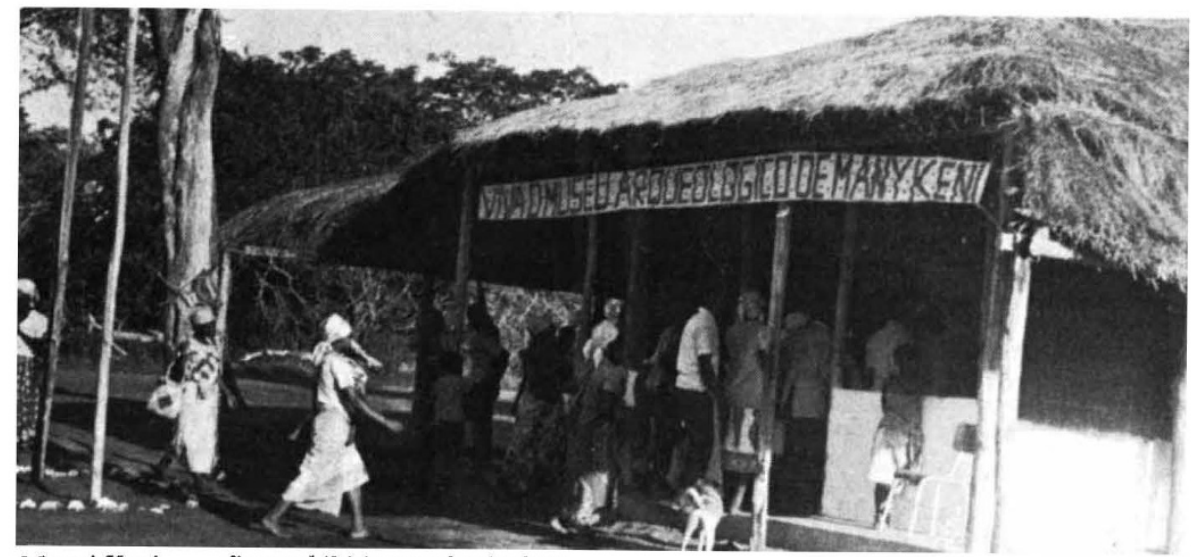

Manyi Keni . . . first exhibition on basic data

produced for Great Zimbabwe, but the then Rhodesian government not only refused to permit them to be displayed, but ordered the removal of all dates from the Zimbabwe displays in museums. And the guidebook was allowed to go out of print. In 1975, when a new guidebook was being written, the government ruled that carbon dates could not be included.

In Mozambique the attitude was different. The Portuguese simply never excavated the Zimbabwes, so there was no data to contradict the Lusatanians.

In 1975, however, after independence in Mozambique one of the Zimbabwes Manyikeni, $50 \mathrm{~km}$ west of Vilanculos was excavated. The work has been done by a Mozambican archaeologist, Joao Morais, and two British archaeologists, Peter Garlake and Paul Sinclair. Both Garlake and Sinclair had worked at Great Zimbabwe, and both quit over the supression of scientific data.

Carbon dating, done free of charge by the University of Rome, shows that Manyikeni was occupied from 1250 to 1750 , and that the walls were built around 1450. The stone walls, about two metres high, and similar to English dry stone walling, made an enclosure inside which about five families lived. The new museum displays show carbon dates and detail the recent excavations and scientific stories.

Several scientific techniques have been brought to bear on the site, some for the first time. One is stratified sampling, in which the site was first divided into 20 metre by 20 metre squares, and then four randomly selected one metre by one metre trenches excavated within each of the larger squares. This gives a better overall picture of life in the settlement than just by digging at "likely looking" spots. Until the early 1970s, all the excavation was done inside the walls. But then it was realised that the bulk of the settlement was actually outside. The area outside is too large to excavate completely and stratified sampling is the only sensible way. Manyikeni is the first Zimbabwe to be extensively excavated outside the walls.

The excavation of this site represents one of Mozambique's first efforts to illuminate its history before the colonists arrived. It also reflects Mozambique's attempt to popularise science. The excavation was done by local people, under the supervision of the professional archaeologists. And the musuem is primarily intended to teach local people their own history. Yet it also represents the first exhibition in Mozambique or Zimbabwe of some basic scientific data.

Joseph Hanlon 